"Mircea cel Batran" Naval Academy Scientific Bulletin, Volume XIX - 2016 - Issue 1

Published by "Mircea cel Batran" Naval Academy Press, Constanta, Romania // The journal is indexed in:

PROQUEST / DOAJ / DRJI / JOURNAL INDEX / I2OR / SCIENCE LIBRARY INDEX / Google Scholar / Crossref /

Academic Keys / ROAD Open Access / OAJI / Academic Resources / Scientific Indexing Services / SCIPIO

\title{
SEAKEEPING ANALYSIS OF SEMISUBMERSIBLES IN IRREGULAR WAVES
}

Ionut-Cristian SCURTU ${ }^{1}$

Adrian POPA ${ }^{2}$

Marian RISTEA ${ }^{3}$

Daniel MARASESCU 4

${ }^{1}$ Principal Instructor, PhD Eng. "Mircea cel Batran" Naval Academy

${ }^{2}$ Assist prof. PhD Eng. "Mircea cel Batran" Naval Academy

${ }^{3}$ Assist. prof. PhD. Eng., Marine Engineering and Naval Weapons Department

${ }^{4} \mathrm{PhD}$ attendee "Mircea cel Batran" Naval Academy, Marine Engineering and Naval Weapons Department

Abstract: Advancement in computer simulated fluid flow and development of hardware resources lead to better simulation in seakeeping analysis. Based on response in regular waves defined by RAO values presented for a three column semisubmersible, the present work will define seakeeping parameters for semisubmersible with two degrees of freedom: heave and pitch. All work will present actual response for different irregular waves. The presented work is valuable for emerging offshore energy converters and oil and gas energy systems and is based on ANSYS CFX simulations for wave response.

Key words: Semisubmersible; wave response; irregular waves, Ansys CFX.

\section{Introduction}

Offshore platforms are floating or fixed large marine structures which is used to house machinery needed to wind and wave energy extraction or for drilling /extracting oil and natural gas. Semisubmersibles are used in offshore wind and wind converters for projects with various shapes and sizes.

For all offshore projects a seakeeping analysis is required in the design and concept process. Semisubmersibles are designed to face environmental loads and to get the best response needed for the onboard operational equipments. In case of a triangular shaped [2] semisubmersible (fig.1.), part of WindFloat project, the seakeeping characteristics will affect turbine maintenance and service intervals.

The present study will present actual response for different irregular waves based on input RAO presented below. In CFX simulations four degrees of freedom are restricted in order to get only heave and pitch.

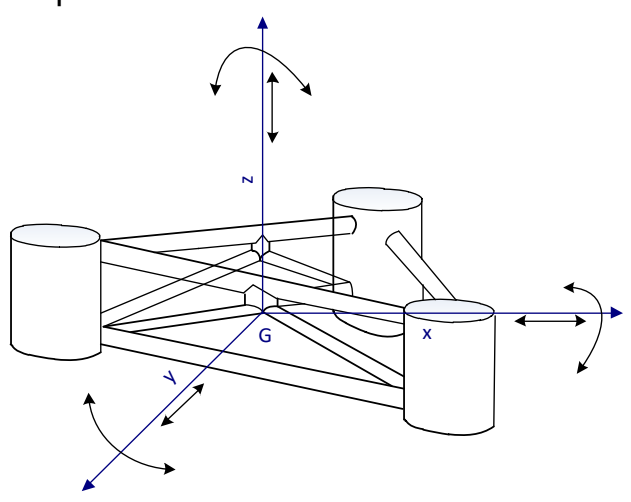

Fig.1. Triangular shaped semisubmersible
Operating in different environmental condition related to extraction area will represent a difficult task to analyze seakeeping properties. An actual response analysis will present results required in a marine environment and will present response in different irregular waves.

Ocean waves are produced by the wind and the wave form is always irregular. If the wind power is higher, the larger waves are formed $[3,4]$. The semisubmersible seakeeping properties depend on the biggest waves produced by a given wind speed during operation. All results are calculated using Pierson-Moskowitz and JONSWAP spectrum for different frequencies.

Input RAO values and description

In CFX simulation of floating semisubmersible in waves we determine values for heave and pitch response in each case of study. All data are processed with the commercial software ANSYS available at CMU (Constanta Maritime University) and results for RAO are input values for the present work. Defining RAO function is enough for regular waves, but in real marine environment waves are irregular and this requires statistical data for operational area.

The semisubmersibles are complex structures and a CFX simulation with VoF method requires high computing capacity and now it can be done using CMU hardware. Wave response in irregular waves is a important issue in offshore designing process.

Tabel 1.1.Input RAO z values for triangular shaped semisubmersibile 
"Mircea cel Batran" Naval Academy Scientific Bulletin, Volume XIX - 2016 - Issue 1

Published by "Mircea cel Batran" Naval Academy Press, Constanta, Romania // The journal is indexed in: PROQUEST / DOAJ / DRJI / JOURNAL INDEX / I2OR / SCIENCE LIBRARY INDEX / Google Scholar / Crossref / Academic Keys I ROAD Open Access / OAJI / Academic Resources / Scientific Indexing Services / SCIPIO

\begin{tabular}{|c|c|}
\hline $\begin{array}{c}\text { Wave } \\
\text { frequency } \\
\text { f w [Hz] }\end{array}$ & $\mathrm{RAO}_{z}$ \\
\hline 0,073 & $0.352 \times 10^{-6}$ \\
\hline 0,085 & $1,610 \times 10^{-6}$ \\
\hline 0,114 & $0,326 \times 10^{-6}$ \\
\hline 0,137 & $0,053 \times 10^{-6}$ \\
\hline 0,144 & $0,245 \times 10^{-6}$ \\
\hline
\end{tabular}

Tabel 1.2. Input RAO RY values for triangular shaped semisubmersibile

\begin{tabular}{|c|c|}
\hline $\begin{array}{c}\text { Wave frequency } \\
\text { f w }[\mathrm{Hz}]\end{array}$ & $\begin{array}{c}\text { RAO } \mathrm{RY} \\
{\left[(\text { grade/m })^{2}\right]}\end{array}$ \\
\hline 0,073 & 0,9021 \\
\hline 0,085 & 25,55 \\
\hline 0,114 & 0,322 \\
\hline 0,137 & 0,196 \\
\hline 0,144 & 0,300 \\
\hline
\end{tabular}

These RAO Z and RAO RY values presented will be used in superposition of wave spectra for any irregular wave studied. The values from tables 1.1. and 1.2. correspond to the initial assumptions and confirms that the presented structure is very stable and hardly influenced by waves. A peak value in both cases is observed on different frequency values and this will modify the response in irregular waves.

VoF method in CFX

ANSYS CFX software use the volume-of-fluid (VOF) method to describe free-surface flows. Extensive Multiphase Flow Capabilities Fluid dynamics simulation provides a wide range of multiphase flow capabilities to meet challenging offshore project needs.

Volume fraction of solid particles in domain simulating the marine environment can be calculated with the Eulerian-granular multiphase flow model in ANSYS CFX software. With the VOF approach, the whole flow domain is meshed with a fixed mesh. The motion and the local volume fraction of the phases are calculated along with the shape of the interface between the two phases: water and air. At any point in space, there is only one or the other of the two fluid phases (fig.2. and 3.), so there is only one velocity field at every location. It is common in CFX practices to solve only one velocity field, although in cases in which the velocity difference along the interface is large, robustness and accuracy of the calculations is improved if two separate velocity fields are solved.

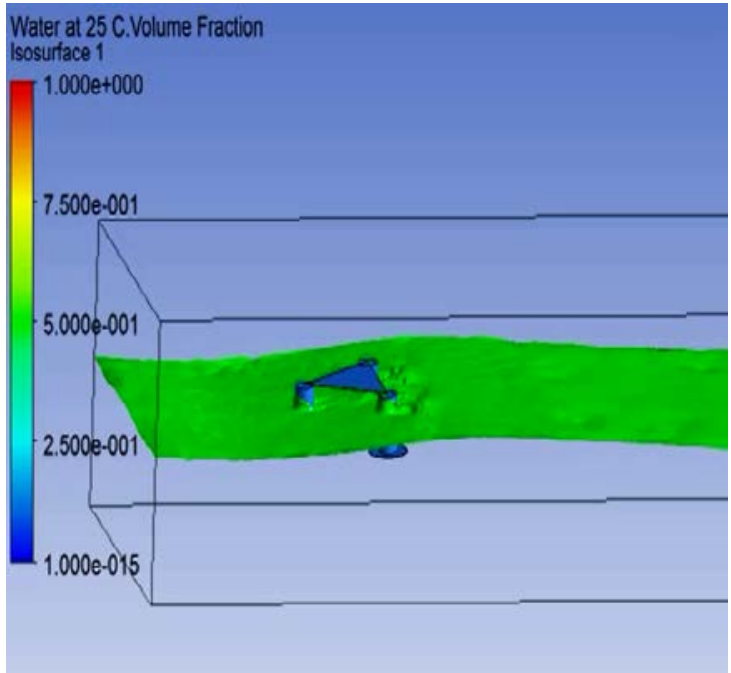

Fig.2. CFX simulation with $\mathrm{VoF} t=3 \mathrm{sec}$

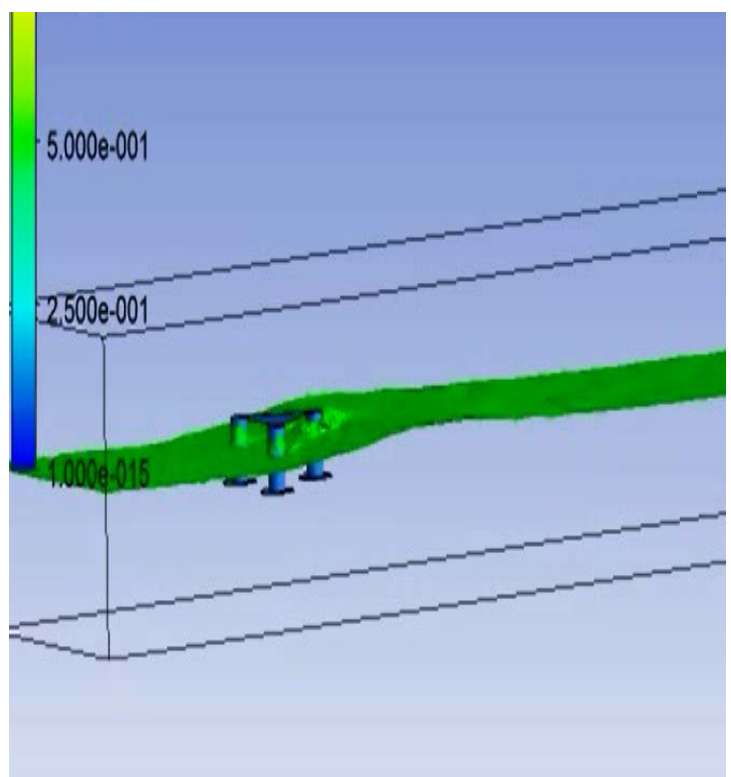

Fig.3. CFX simulation $\mathrm{t}=6 \mathrm{sec}$

The shape of the fluid interface does not have to match the shape of the mesh. Different interface tracking methods are available with different levels of accuracy, calculation speed and numerical robustness. The presented example of the use of the VOF model in case of floating structures is based on stratified flows (distinct layers of different fluids).

\section{Use the RAO for irregular waves}

The principle of this transformation in energy wave energy response is shown in fig. 4 for vertical movement considered in the analysis.

Each regular element wave[1] can be transferred to a component of vertical movement using the multiplier $z_{-} a / \zeta \_a(\omega)$. The result can be seen on the right side of the fig. 3. History irregular vertical motion $\mathrm{z}(\mathrm{t})$, is obtained by adding components vertical motion as did the wave in the left. Tracing $z_{-} a^{\wedge} 21 / 2$ value $(\omega) / \Delta \omega$ of each component of 
"Mircea cel Batran" Naval Academy Scientific Bulletin, Volume XIX - 2016 - Issue 1

Published by "Mircea cel Batran" Naval Academy Press, Constanta, Romania /I The journal is indexed in: PROQUEST / DOAJ / DRJI / JOURNAL INDEX / I2OR / SCIENCE LIBRARY INDEX / Google Scholar / Crossref I

Academic Keys I ROAD Open Access / OAJI / Academic Resources / Scientific Indexing Services / SCIPIO

$\omega$-axis vertical movement on the right resulting vertical motion response spectrum $S \_z(\omega)$.

Moments vertical motion response spectrum is given by:

$$
m_{n z}=\int_{0}^{\infty} S_{z}(\omega) \cdot \omega^{n} d \omega, \text { cu } n=0,1,2, \ldots
$$

Where $\mathrm{n}=0$ is the $\mathrm{n}=1$ and $\mathrm{n}=2$ the first moment of inertia when the curve of the spectrum. The amplitude of vertical movement signified can be calculated from spectral density function vertical movements, just as was done for waves. Significant vertical movement amplitude, defined as the average of the three largest amplitude is:

$$
\bar{z}_{a_{1 / 3} / 3}=2 \cdot R M S=2 \sqrt{m_{0 z}}
$$

A median may be inferred from the center of gravity of the spectrum

$$
T_{1 z}=2 \pi \cdot \frac{m_{0 z}}{m_{1 z}}
$$

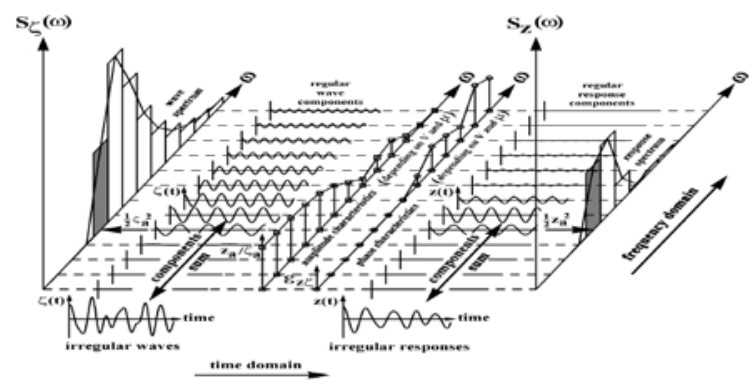

Fig.4. The principle of the wave spectrum response [6]

Another definition, which is equal to the average zero-crossing period, it is inferred from the spectral radius of gyration[6]:

$$
T_{2 z}=2 \pi \cdot \sqrt{\frac{m_{0 z}}{m_{2 z}}}
$$

With this principle in irregular waves transfer answers can bring an answer to any irregular wave after the above scheme. Summing regular responses RAO known together using analysis of any situation that makes it easy to meet in the operation of a semisubmersible structure.

Results for semi-submersible functions RAO 3 columns spectrum JONSWAP

Based on the response spectrum can be calculated JONSWAP semisubmersible structure by converting each component of the response spectrum and then by superimposing the results structure will get answers in various frequencies(fig.5-10.).

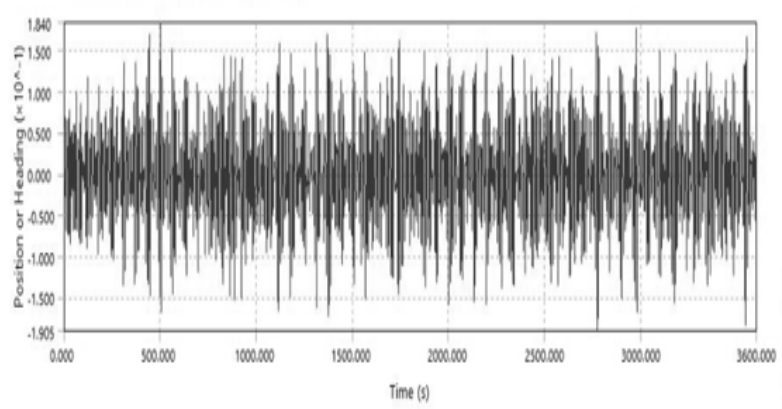

Fig 5. Response in RX direction based on RAO to $\mathrm{Hs}=1.2 \mathrm{~m}$ Jonswap, $0.1 \mathrm{~Hz}$ peak $\mathrm{t}=3600 \mathrm{sec}$

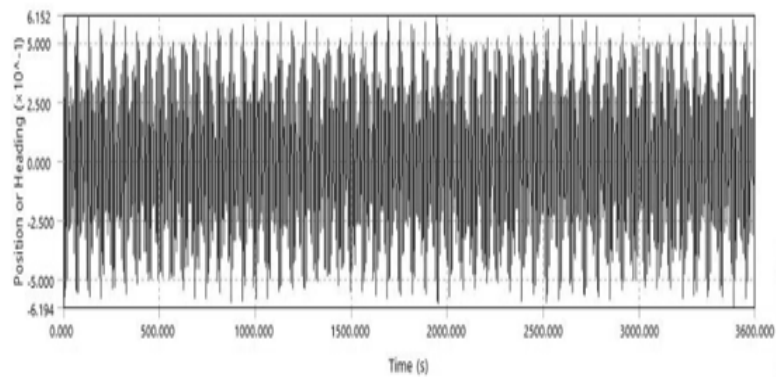

Fig.6. Response in $Z$ direction based on RAO to $\mathrm{Hs}=1.2 \mathrm{~m}$ Jonswap, $0.1 \mathrm{~Hz}$ peak $\mathrm{t}=3600 \mathrm{sec}$

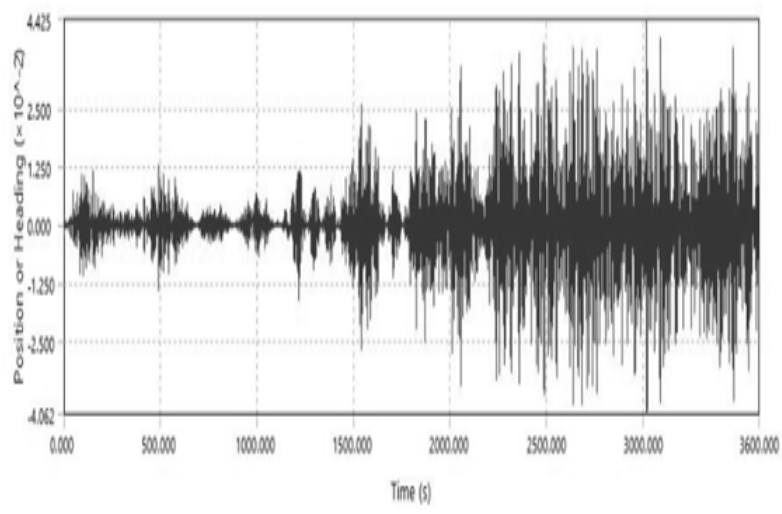

Fig. 7. Response in $\mathrm{RX}$ direction based on RAO to $\mathrm{Hs}=1.2 \mathrm{~m}$ Jonswap, $0.66 \mathrm{~Hz}$ peak $\mathrm{t}=3600 \mathrm{sec}$

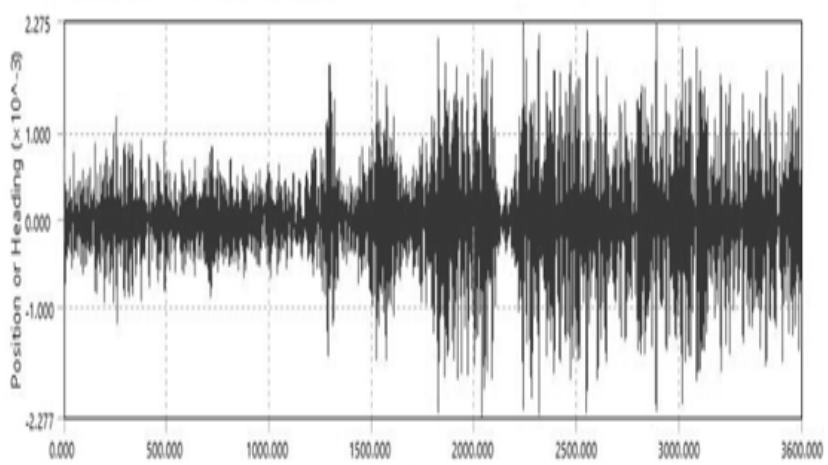

Fig. 8. Response in $Z$ direction based on RAO to $\mathrm{Hs}=1.2 \mathrm{~m}$ Jonswap, $0.66 \mathrm{~Hz}$ peak $\mathrm{t}=3600 \mathrm{sec}$ 
"Mircea cel Batran" Naval Academy Scientific Bulletin, Volume XIX - 2016 - Issue 1

Published by "Mircea cel Batran" Naval Academy Press, Constanta, Romania // The journal is indexed in: PROQUEST / DOAJ / DRJI / JOURNAL INDEX / I2OR / SCIENCE LIBRARY INDEX / Google Scholar / Crossref /

Academic Keys / ROAD Open Access / OAJI / Academic Resources / Scientific Indexing Services / SCIPIO

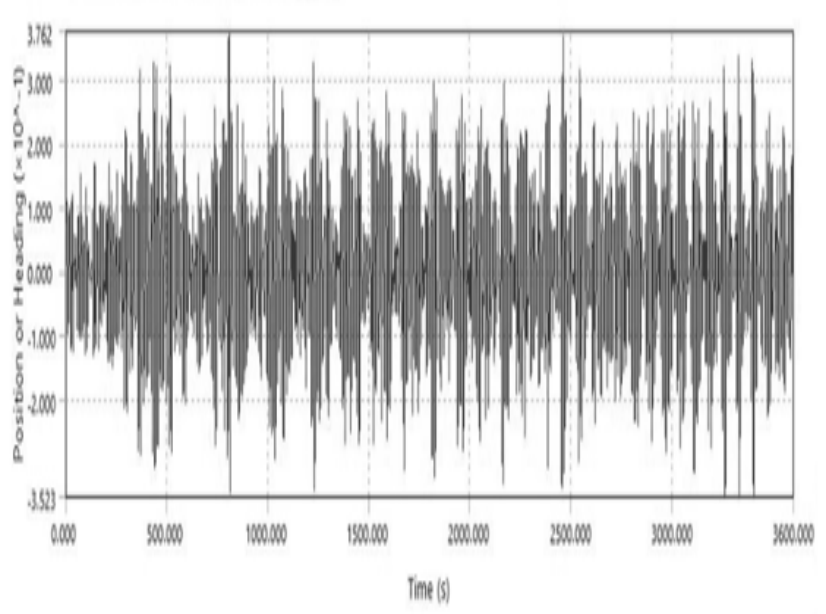

Fig. 9. Response in RX direction based on RAO to $\mathrm{Hs}=1.2 \mathrm{~m}$ Jonswap, $0.085 \mathrm{~Hz}$ peak $\mathrm{t}=3600 \mathrm{sec}$

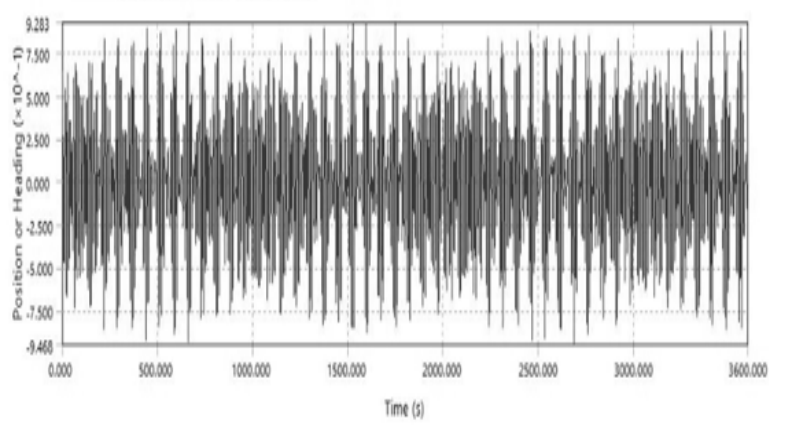

Fig. 10. Response in $\mathrm{Z}$ direction based on RAO to $\mathrm{Hs}=1.2 \mathrm{~m}$ Jonswap, $0.085 \mathrm{~Hz}$ peak $\mathrm{t}=3600 \mathrm{sec}$

Using the Jonswap actual response for center of gravity maximum values for $\mathrm{Hs}=1.2 \mathrm{~m}$ presented for response in $Z$ and $R X$ in figure 11 .
The five test cases presented show the different variation in Jonswap with $y=1$. At frequency $0,066 \mathrm{~Hz}$ occurs the smallest heave and pitch in the Jonswap spectrum for wave of $1.2 \mathrm{~m}$.

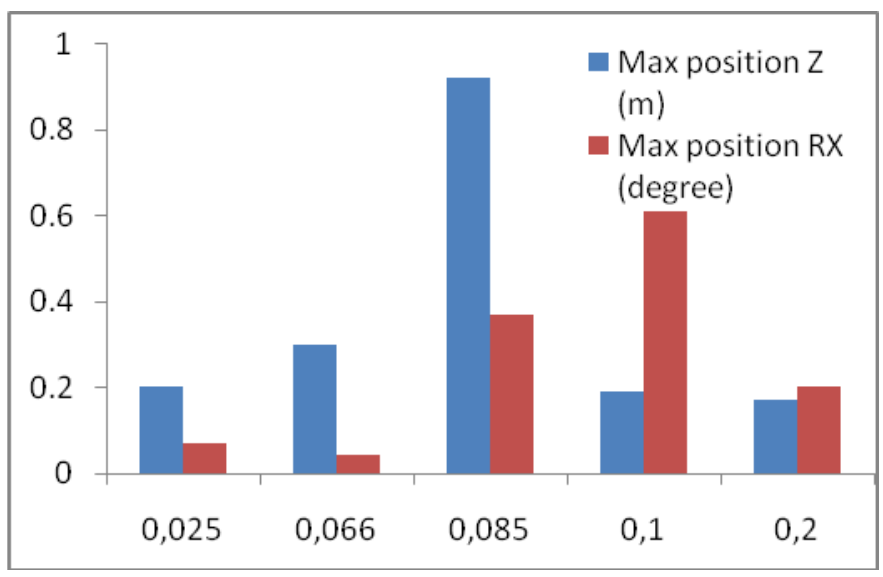

Fig. 11. Maximum Jonswap position $Z$ and $R X$ in Jonswap for $\mathrm{Hs}=1.2 \mathrm{~m}$

Based on response in regular waves we can evaluate response in any other known spectrum and for a specified wave height we can estimate seakeeping parameters like heave and pitch as presented in fig. 11. Operational seakeeping needs can be verified using the present values in case of a triangular shaped semisubmersible.

\section{CONCLUSIONS}

This work has reviewed and reported the state of art in ANSYS CFX simulations for wave response. In this seakeeping analysis we have shown that semisubmersible heave and pitch based on input RAO parameters and strong CFX software analysis.

This work has presented an seakeepng analysis that can help in software simulations in ANSYS CFX with VoF method and giving the needed information in the offshore industry projects. Values presented of a triangular shaped semisubmersible based on Ansys CFX simulated RAO are defining well seakeeping parameters required in heave and pitch analysis.

The construction of "Maximum Jonswap position Z and RX in a specified wave height" is an original concept tool for real marine waves evaluation. The analysis reported in this paper can be further explored to develop semisubmersible related seakeeping parameters for further development of the offshore structures. The JONSWAP spectrum is used to present actual response for different irregular waves.

\section{BIBLIOGRAPHY}

[1] Abhilash Somayajula, Jeffrey Falzarano, Large-amplitude time-domain simulation tool for marine and offshore motion prediction, Marine Systems \& Ocean Technology, March 2015, Volume 10, Issue 1, pp 1-17 [2] Naoya Umeda, Satoshi Usada, Kentaro Mizumoto,Akihiko Matsuda, Broaching probability for a ship in irregular stern-quartering waves: theoretical prediction and experimental validation, Journal of Marine Science and Technology, March 2016, Volume 21, Issue 1, pp 23-37

[3] Guanche Y., Guanche R., Camus P., Fernando J. Méndez, Raúl Medina., A multivariate approach to estimate design loads for offshore wind turbines, Environmental Hydraulics Institute "IH Cantabria" Universidad de Cantabria E.T.S de Ingenieros de Caminos, Canales y Puertos Avda. Los Castros, s/n.39005, Santander, Spain 
"Mircea cel Batran" Naval Academy Scientific Bulletin, Volume XIX - 2016 - Issue 1

Published by "Mircea cel Batran" Naval Academy Press, Constanta, Romania // The journal is indexed in:

PROQUEST / DOAJ / DRJI / JOURNAL INDEX / I2OR / SCIENCE LIBRARY INDEX / Google Scholar / Crossref /

Academic Keys / ROAD Open Access / OAJI / Academic Resources / Scientific Indexing Services / SCIPIO

[4] Gunter Claus, Eike Lehmann, Carsten Ostregaard, Offshore Structures Volume I, Conceptual design and hydromechanics, Springer-Verlag, ISBN 3-540-19709-5.

[5] Journée J.M.J., Massie W.W., Offshore hydromechanics, First Edition, Delft University of Technology, 2001

[6] Oncica V. , Pricop M., Chiţac V., Zus M., Influenţa formelor navei şi a adâncimii apei sub chilă asupra vibraţiilor verticale ale grinzii navă de secţiune constantă, A XIX a Sesiune de comunicări ştiinţifice cu participare internaţională NAV-MAR-EDU 2005, Constanţa,

[7] Overview Of Seakeeping, www.ultramarine.com/hdesk/runs/samples/sea_keep/doc.htm Accesed 22.01.2016

[8] Pricop M., Algoritm de calcul al bracheţilor structurilor navale, ANALELE Universităţii din Oradea, Fascicola Mecanică, Secţiunea Mecanică, Rezistenţa Materialelor, Vibraţii, 1997, p. 205-211.

[9] Pricop M., Chiţac, V., Oncica V., Zus N. M. 2005, Computation of the added masses of ship's hull vertical vibrations in shallow waters, Rev. Meridian ingineresc 4/2005, pag.51-55, ISSN 1683-853X, Chişinău, Republica Moldova.

[10] Pricop M., Analiza răspunsului dinamic al corpului navei utilizând matricea dinamică de transmitere, public. în Proc. THE 17th INTERNATIONAL SYMPOSIUM „NAV-MAR-EDU 2001” ON NAVAL AND MARINE EDUCATION, 24-26 mai 2001, Constanţa, ISBN 973-85070-0-6.

[11] Scurtu I.-C., Pricop M., Oncica Valentin, Stability analysis of modern offshore semisubmersibles, "Mircea cel Batran" Naval Academy Scientific Bulletin, Volume XVIII - 2015 - Issue 2, ISSN: 2392-8956, pag. 40-45;

[12] Pricop, M., Florin Gheorghe, F., Pazara T., Simulation of static and dynamic behaviour of the wave energy collector in real sea, Buletinul Universităţii Petrol-Gaze, Ploieşti, Seria TEHNICĂ, Vol. LXIII, No 1/2011, ISSN 12248495, pag.147-154, cotată B+, Cod CNCSIS 37 